CHRONIC OBSTRUCTIVE PULMONARY DISEASE

\title{
Oxidative stress and airway inflammation in severe exacerbations of COPD
}

\author{
E M Drost, K M Skwarski, J Sauleda, N Soler, J Roca, A Agusti, W MacNee
}

Thorax 2005;60:293-300. doi: 10.1136/thx.2004.027946

See end of article for authors' affiliations

.....................

Correspondence to: Dr E M Drost, ELEGI Laboratory, MRC Centre for Inflammation Research, University of Edinburgh, Medical School, Teviot Place, Edinburgh EH8 9AG, UK; Ellen.Drosł@ed. ac.uk

Received 25 May 2004

Accepted

19 December 2004
Background: A study was undertaken to assess both oxidative stress and inflammation in the lungs of patients with chronic obstructive pulmonary disease (COPD) during severe and very severe exacerbations compared with those with stable COPD, healthy smokers, and non-smokers. Two sites within the lungs were compared: the large airways (in sputum) and the peripheral airways (by bronchoalveolar lavage (BAL)).

Methods: BAL fluid cell numbers and levels of tumour necrosis factor (TNF $\alpha$ ) and interleukin (IL)-8 were measured as markers of airway inflammation and glutathione (GSH) levels as a marker of antioxidant status. Nuclear translocation of the pro-inflammatory transcription factors nuclear factor- $\kappa B(N F-\kappa B)$ and activator protein 1 (AP-1) were also measured by electromobility shift assay in BAL fluid leucocytes and lung biopsy samples.

Results: Influx of inflammatory cells into the peripheral airways during exacerbations of COPD was confirmed. Increased IL-8 levels were detected in BAL fluid from patients with stable COPD compared with non-smokers and healthy smokers, with no further increase during exacerbations. In contrast, IL-8 levels in the large airways increased during exacerbations. GSH levels were increased in the BAL fluid of smokers $(444 \%)$ and patients with stable COPD $(235 \%)$ compared with non-smokers and were reduced during exacerbations (severe $89.2 \%$; very severe $52.3 \%$ compared with stable COPD). NF- $\kappa B$ DNA binding in BAL leucocytes was decreased in healthy smokers compared with non-smokers $(41.3 \%, n=9, p<0.001)$ but did not differ in COPD patients, whereas AP-1 DNA binding was significantly decreased during exacerbations of COPD.

Conclusion: There is evidence of increased oxidative stress in the airways of patients with COPD that is increased further in severe and very severe exacerbations of the disease. This is associated with increased neutrophil influx and IL-8 levels during exacerbations. l: nflammation is a prominent feature of chronic obstructive pulmonary disease (COPD) as shown by the presence in the airways of activated neutrophils and macrophages and increased numbers of inflammatory mediators. ${ }^{12}$ A current hypothesis in the pathogenesis of COPD is that the increased oxidant burden-both directly as a result of smoking or indirectly by the release of increased amounts of reactive oxygen species from airspace leucocytes-may not be adequately counterbalanced by the lung antioxidant systems, resulting in oxidative stress. An excess of oxidants may then lead to enhanced pro-inflammatory gene expression and protein release, inactivation of antiproteases, and oxidative tissue injury leading to COPD.

The presence of oxidative stress in the airways of smokers and patients with COPD has been shown by increased products of lipid peroxidation and altered antioxidant status. $^{3-5}$ Transcription factors such as nuclear factor- $\kappa \mathrm{B}$ $(\mathrm{NF}-\kappa \mathrm{B})$ and activator protein $\mathrm{l}$ (AP-1) that are important for gene transcription of the inflammatory cytokines associated with airway inflammation in COPD—such as interleukin (IL) -8, tumour necrosis factor $\alpha(\mathrm{TNF} \alpha)$, and IL-6 ${ }^{12}{ }^{6}$-are oxidant sensitive. ${ }^{7}$ We also recently found an increase in NF$\kappa \mathrm{B}$ nuclear translocation in airway leucocytes from COPD patients during an exacerbation compared with leucocytes from stable patients. ${ }^{8}$ Furthermore, we found the sequestration of neutrophils in the pulmonary micropreparative increased during active cigarette smoking and in COPD patients undergoing an exacerbation, an effect that may be oxidant mediated. ${ }^{9-11}$ These data suggest that lung oxidative stress and inflammation in COPD may be linked.
Glutathione (GSH) is the principal small molecular weight thiol in the lungs which, together with its redox enzymes, provides an important protective antioxidant system. Studies show depletion of GSH in lung cells in vitro and in rat lungs in vivo following acute exposure to cigarette smoke, with a rebound increase in levels over time. ${ }^{12}{ }^{13}$ These findings are in agreement with the high levels of GSH reported in the epithelial lining fluid of smokers. ${ }^{14}$ Changes in GSH levels were found to be due to inhibition (by acute smoking) and then enhanced activation of the rate limiting enzyme for GSH production, gamma-glutamylcysteine synthetase $\left(\gamma\right.$-GCS). ${ }^{15}$ The regulation of this gene was linked with the redox sensitive transcription factor, AP- $1 .{ }^{15}$

Exacerbations of COPD are considered to reflect worsening of the underlying chronic inflammation in the airways. However, there is little information on the inflammatory responses in the lungs in exacerbations of COPD, particularly during severe exacerbations. Patients with COPD are known to have increased numbers of activated neutrophils in their airways. These neutrophils are believed to be attracted to the airways by the cytokines IL- 8 and TNF $\alpha$ which are present in increased levels in the lungs of patients with stable COPD. ${ }^{1}$ Further increases in the levels of cytokines and also increased cell numbers in the large airways have been reported during exacerbations of the disease. ${ }^{2}$ Moreover, the frequency of

Abbreviations: AP-1, activator protein 1; COPD, chronic obstructive pulmonary disease; EMSA, electrophoretic mobility shift assay, $\gamma$-GCS, gamma-glutamylcysteine synthetase; GSH, glutathione; IL, interleukin; $\mathrm{NF}-\kappa \mathrm{B}$, nuclear factor- $\kappa \mathrm{B} ; \mathrm{TNF} \alpha$, tumour necrosis factor $\alpha$ 
exacerbations is associated with disease severity ${ }^{16}$ and a further increase in airways inflammation. ${ }^{2}$ These patients have a reduced quality of life and significantly more hospital admissions and a longer time in hospital, thereby adding to the socioeconomic burden.

The aim of this study was to assess the oxidant/antioxidant imbalance and markers of inflammation in both the proximal and distal compartments of the lungs in patients with severe and very severe exacerbations of COPD. It is known that samples from the different compartments of the lungs yield differences in cell numbers, markers of inflammation and oxidative stress. We therefore set out to assess the extent and location of inflammation in these patients. Specifically, we studied the antioxidant GSH, cell numbers, and the inflammatory mediators $\mathrm{TNF} \alpha$ and IL- 8 in proximal and distal airways.

\section{METHODS}

\section{Study subjects}

Three groups of patients with COPD were studied. A group with moderate COPD (GOLD stage II), diagnosed in accordance with GOLD guidelines, ${ }^{17}$ were studied when clinically stable at least 6 weeks after their last exacerbation, and two groups of patients with severe COPD were studied during exacerbations with severity assessed by healthcare utilisation according to the European Respiratory Society COPD guidelines. ${ }^{18}$ Exacerbations were defined as an increase in symptoms beyond normal day-to-day variation requiring a change in medication and hospital admission. According to a recent consensus statement on exacerbations, these patients could be divided into those with severe exacerbations (GOLD stage III) requiring hospital admission, and those with very severe exacerbations (GOLD stage IV) who had respiratory failure and required intervention with mechanical ventilation. ${ }^{18}$ Patients with severe or very severe exacerbations of COPD were studied within 48 hours of admission to hospital or the intensive care unit. Exclusion criteria were age less than 40 years; pneumonia or other lung diseases; a history suggestive of asthma; and treatment with oral corticosteroids, non-steroidal anti-inflammatory agents, or theophylline preparations during the 2 weeks before admission. Healthy non-smokers and smokers formed control groups for comparison. Smokers had not smoked for 12 hours before bronchoscopy to exclude the acute effects of smoking.

All subjects were informed of the nature and purpose of the study and gave their consent or, in the case of ventilated patients, consent was obtained from their relatives. The studies were approved by the local hospital ethics committees in Barcelona and Palma de Mallorca for the studies in patients with exacerbations and by the Lothian ethics committee for studies in healthy subjects, smokers, and those with stable COPD studied in Edinburgh. All procedures were standardised across the three study centres.

\section{Bronchoscopy and bronchoalveolar lavage (BAL)}

All study subjects underwent bronchoscopy. Patients with very severe exacerbations were ventilated and bronchoscopic examination was undertaken via an endotracheal tube. The other groups had fibreoptic bronchoscopy under local anaesthetic. Topical lignocaine was applied to the nasopharynx $(0.5 \mathrm{ml}$ of $0.4 \%$ solution and $2 \mathrm{ml}$ of $0.2 \%$ solution) and to the vocal cords and major airways (6 $\mathrm{ml}$ of $2 \%$ solution). Subjects were given oxygen at $2 \mathrm{l} / \mathrm{min}$ throughout the procedure. Two separate samples were obtained: (1) large airways secretions and (2) bronchoalveolar lavage (BAL) fluid from a segment of the middle lobe or lingula. Resident mucus was aspirated from the trachea and main bronchi to represent a large airways sample. The collection receptacle was then changed before BAL was performed using up to
$240 \mathrm{ml}$ warmed saline in $30 \mathrm{ml}$ aliquots and aspirated immediately using a low suction rate. This technique samples the distal airways and alveoli. ${ }^{19}$

A biopsy sample was taken from a segmental bronchus where possible and frozen immediately at $-80^{\circ} \mathrm{C}$. Biopsy specimens were homogenised in cytoplasmic extraction buffer containing 10\% Nonidet-40 (NP40) as described for electrophoretic mobility shift assay (EMSAs) and nuclear proteins extracted as detailed below.

\section{Processing of proximal and distal airway samples}

The sample of proximal large airway secretions was weighed and an equal volume of dithiotreitol (DTT) (stock $1 \%$ in distilled water diluted to $0.1 \%$ in phosphate buffered saline (PBS)) was added. The sample was mixed on ice for 15 minutes, following which an equal volume of PBS was added and the solution filtered through $48 \mu \mathrm{m}$ nylon gauze. The supernatant was centrifuged at a relative centrifugal force of $1050 \mathrm{~g}$ for 10 minutes at $4^{\circ} \mathrm{C}$. The cell pellet was discarded and aliquots of the spun supernatant were stored at $-70^{\circ} \mathrm{C}$.

BAL fluid from the distal airspaces was filtered through sterile gauze swabs and centrifuged at $242 \mathrm{~g}$ for 10 minutes at $4^{\circ} \mathrm{C}$. The supernatant was decanted and spun at $1050 \mathrm{~g}$ for 10 minutes at $4^{\circ} \mathrm{C}$ and aliquoted for storage at $-70^{\circ} \mathrm{C}$ for later analysis. The cell pellet obtained from the BAL fluid was washed in PBS and counted with a haemocytometer. Viability was ascertained by exclusion of trypan blue. Cytospins were prepared in a Shandon cytospin 3 (Shandon, Pittsburgh, PA, USA) and stained with DiffQuick stain (Merz Dade, Switzerland). Cell differential counts were determined by counting 200 cells per sample.

\section{Assays}

All reagents were obtained from Sigma (Poole, UK) unless stated otherwise.

\section{Glutathione}

Reduced glutathione (GSH) was measured in BALF fluid by the method of Tietze ${ }^{20}$ with modifications for a 96 well plate. ${ }^{21}$ Large airway secretions were not assessed for GSH as the presence of DTT interferes with the GSH assay (by interacting with GSH reductase). The reaction rate of DTNB, NADPH, and GSH reductase was measured over 6 minutes at an absorbance of $410 \mathrm{~nm}$ using a Dynex MRX plate reader. A standard curve of GSH in the range of $0.25-16 \mu \mathrm{g} / \mathrm{ml}$ was used. The results were expressed as ng GSH/mg total protein, as measured by the Pierce bicinchoninic acid (BCA) protein assay (Pierce and Warriner (UK) Ltd, Chester, UK).

\section{IL- 8 and TNF $\alpha$ ELISAs}

IL-8 and TNF $\alpha$ concentrations in large airway and BAL fluid samples were assessed by a human enzyme-linked immunosorbent sandwich assay (ELISA) using specific monoclonal biotinylated antibodies (R\&D Systems, Oxon, UK) and a streptavidin peroxidase (Dako Ltd, Ely, UK)/3,3',5, 5' -tetramethylbenzidine (Boehringer Mannheim, East Sussex, UK) detection system. Sulphuric acid was added to terminate the reaction and the optical density was determined at $450 \mathrm{~nm}$. Cytokine levels were expressed as $\mathrm{pg} / \mathrm{ml}$ or $\mathrm{ng} / \mathrm{ml}$. For BAL fluid, the data were expressed per mg protein (as measured by the Pierce BCA protein assay) to account for the different volumes of saline instilled during lavage. DTT and lignocaine did not interfere with the ELISAs (data not shown).

\section{Electrophoretic mobility shift assay (EMSA)}

Nuclear proteins were extracted from mixed leucocytes obtained from BAL fluid and lung biopsies by the method of Andrews and Faller. ${ }^{22}$ The cells were incubated in 
Table 1 Characteristics of subjects

\begin{tabular}{|c|c|c|c|c|c|}
\hline & $\begin{array}{l}\text { Non-smokers } \\
(n=10)\end{array}$ & $\begin{array}{l}\text { Healthy smokers } \\
(n=12)\end{array}$ & $\begin{array}{l}\text { Stable COPD } \\
(n=7)\end{array}$ & $\begin{array}{l}\text { Severe exacerbations } \\
\text { of COPD } \\
(n=7)\end{array}$ & $\begin{array}{l}\text { Very severe exacerbations } \\
\text { of COPD } \\
(\mathrm{n}=7)\end{array}$ \\
\hline $\begin{array}{l}\text { Age (years) } \\
\mathrm{M} / \mathrm{F} \\
\mathrm{FEV} \\
\mathrm{FEV}_{1} \text { when stable (l) } \\
\mathrm{FEV} \mathrm{F}_{1} / \mathrm{FVC} \text { ratio }(\%) \\
\mathrm{Smoking} \text { (pack years) } \\
\mathrm{PaO}_{2} / \mathrm{PaCO}_{2} \text { (kPa) } \\
\text { Oral corticosteroids (Y/N) } \\
\text { Inhaled corticosteroids (Y/N) }\end{array}$ & $\begin{array}{l}53.5(2.5) \\
4 / 6 \\
3.4(0.4) \\
116.3(7.7) \\
75.3(2.6) \\
\text { NA } \\
\text { ND } \\
-/-\end{array}$ & $\begin{array}{l}50.3(2.1) \\
6 / 6 \\
3.1(0.2) \\
98.5(3.9) \text { * } \\
74.4(1.8) \\
41(6) \\
\text { ND } \\
-/-\end{array}$ & $\begin{array}{l}70.3(5.4)^{* *}+\dagger \dagger \\
4 / 3 \\
2.47(0.4)^{* *} \\
63.7(7.5)^{* * *} \dagger \\
58.8(2.9) \\
38(12) \\
N D \\
-/ 7 \\
-/ 7\end{array}$ & $\begin{array}{l}57.8(3.5) \\
7 / 0 \\
0.89(0.2)^{\star * *}+\dagger \dagger \\
28.6(0.14)^{* * *}+\dagger \\
42.8(6.5)^{\star *} \dagger \\
52(5) \\
8.9(0.4) / 6.0(0.3) \\
-/ 8 \\
2 / 5\end{array}$ & $\begin{array}{l}69.9(1.6)^{* *}+\dagger \dagger \\
7 / 0 \\
0.9(0.2)^{* * *}+\dagger \dagger \\
31.4(6.9)^{* * *}+\dagger \dagger \\
46.0(7.2)^{* *} \dagger \\
58(6) \dagger \\
6.7(1.4) / 9.1(1.1) \\
3 / 5 \\
7 / 1\end{array}$ \\
\hline
\end{tabular}

Values are shown as mean (SE).

$\mathrm{FEV}_{1}$, forced expiratory volume in 1 second; $\mathrm{FVC}$, forced vital capacity; $\mathrm{PaO}_{2}, \mathrm{PaCO}_{2}$, arterial oxygen and carbon dioxide tensions; $\mathrm{NA}$, not applicable; $\mathrm{ND}$, not done.

${ }^{*} \mathrm{p}<0.05,{ }^{* *} \mathrm{p}<0.01,{ }^{* * *} \mathrm{p}<0.001$ compared with non-smokers.

$\dagger p<0.05,+\uparrow p<0.01$, $+\uparrow+p<0.001$ compared with smokers.

cytoplasmic extraction buffer (10 mM Hepes-KOH, pH 7.9, $1.5 \mathrm{mM} \mathrm{MgCl}_{2}, 10 \mathrm{mM} \mathrm{KCl}, 0.5 \mathrm{mM}$ DTT and $1 \mu \mathrm{g} / \mathrm{ml}$ leupeptin, $1 \mu \mathrm{g} / \mathrm{ml}$ aprotinin, $1 \mu \mathrm{g} / \mathrm{ml}$ pepstatin, $10 \mu \mathrm{M} 4-$ (2-aminomethylbenzensulfonyl fluoride)) for 15 minutes on ice and lysed with 10\% Nonidet-40 (NP-40). After centrifugation the nuclei were resuspended in hypertonic nuclear extraction buffer $(20 \mathrm{mM}$ Hepes-KOH, $420 \mathrm{mM} \mathrm{NaCl}$, $1.5 \mathrm{mM} \mathrm{MgCl} 2,0.2 \mathrm{mM}$ EDTA, $0.5 \mathrm{mM}$ DTT, $25 \%$ glycerol containing $1 \mu \mathrm{g} / \mathrm{ml}$ leupeptin, $1 \mu \mathrm{g} / \mathrm{ml}$ aprotinin, $1 \mu \mathrm{g} / \mathrm{ml}$ pepstatin, $10 \mu \mathrm{M}$ 4-2(aminomethylbenzenesulfonyl fluoride, $10 \mu \mathrm{M}$ glycerophosphate, $1 \mu \mathrm{M} \mathrm{Na} \mathrm{VO}_{4}$ ) for 20 minutes on ice. The samples were centrifuged and the supernatant stored at $-70^{\circ} \mathrm{C}$. Biopsy specimens were homogenised in cytoplasmic extraction buffer and the procedure followed as for BAL fluid leucocytes.

EMSAs were performed as previously described.$^{23}$ Seven $\mu \mathrm{g}$ of nuclear protein (as determined using the Bio-Rad protein assay) were incubated in binding buffer $(50 \mathrm{mM}$ Tris- $\mathrm{HCl}$ $\mathrm{pH} 7.0,500 \mathrm{mM} \mathrm{KCl}, 5 \mathrm{mM}$ DTT, $5 \mathrm{mM}$ EDTA, $2.5 \mathrm{mM}$ $\mathrm{MgCl}_{2}, 40 \%$ glycerol with $1 \mu \mathrm{g}$ poly (dI-dC).poly(dI-dC) added per reaction) with $\gamma-{ }^{32} \mathrm{P}$-ATP (Amersham, Buckinghamshire, UK) end labelled consensus oligonucleotides for NF- $\kappa$ B and AP- 1 (Promega, Southampton, UK). The sequences of oligonucleotides used for EMSAs were: NF- $\kappa \mathrm{B}$ sense 5'-AGTTGAGGGGACTTTCCCAGG-3', AP-1 sense 5'CGCTTGATGAGTCAGCCGGAA-3'. Binding was allowed to proceed for 20 minutes at room temperature and electrophoresed on a $6 \%$ non-denatured polyacrylamide gel in IX Tris-buffered-EDTA (TBE) buffer. Specificity was determined by 100 fold excess addition of a cold unlabelled corresponding oligonucleotide (cold competitor) and a different oligonucleotide (non-competitor). Gels were dried onto Whatman paper and exposed for autoradiography. The retarded oligonucleotides were visualised by a Storm 860 phosphoimager and the intensity of the NF- $\mathrm{KB}$ bands were quantified using ImageQuant Analysis (Molecular Dynamics Inc, Buckinghamshire, UK).

\section{Statistical analysis}

Spirometric data, differential cell counts, and leucocyte NF$\kappa \mathrm{B}$ DNA binding data were normally distributed and were expressed as mean (SE) values. Differences between the means were assessed by a one-way analysis of variance (ANOVA). Student-Newman-Keuls post tests were performed when a significant difference between the groups was obtained. Data for non-normally distributed variables (GSH, TNF $\alpha$ and IL-8 levels, and leucocyte and biopsy AP-1 and biopsy NF- $\mathrm{KB}$ ) were expressed as medians with interquartile ranges (IQR), and statistical analysis was performed

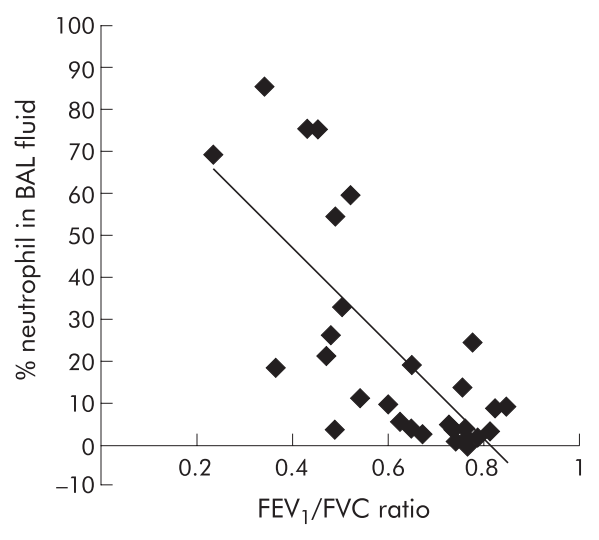

Figure 1 Relation between percentage neutrophils in BAL fluid and $\mathrm{FEV}_{1} / \mathrm{FVC}$ ratio. A significant linear relationship was seen between the percentage of neutrophils in the BAL fluid and the severity of airways obstruction as assessed by $\mathrm{FEV}_{1} / \mathrm{FVC}$ ratio for all subjects ( $r=-0.751$, $n=34, p<0.0001$ ).

by Kruskal-Wallis ANOVA and Dunn's multiple comparison post hoc pairwise comparison when significant differences were found. A p value of $<0.05$ was considered significant. To assess the relationship between variables, linear regressions were performed on all the data as the numbers were too low in the subgroups to confirm such correlations.

\section{RESULTS}

\section{Subjects}

Twenty one patients with COPD were studied: seven with moderate COPD were studied when stable, seven with a severe exacerbation, and seven with a very severe exacerbation of COPD and respiratory failure. Ten non-smokers and 12 smokers with no respiratory symptoms and normal spirometric data were studied for comparison. The characteristics of the subjects at the time of enrolment into the study are shown in table 1. All healthy subjects had normal lung function. Non-smokers and healthy smokers were younger than those with stable COPD and those with severe exacerbations. Patients with very severe exacerbations of COPD had a significantly greater number of pack years of smoking than healthy smokers $(\mathrm{p}<0.05)$, although all smokers had at least a 22 pack year history. Significant differences in $\%$ predicted forced expiratory volume in 1 second $\left(\mathrm{FEV}_{1}\right)$ and ratio of $\mathrm{FEV}_{1}$ to forced vital capacity (FVC) are evident between the groups (table 1). 
Table 2 Total and differential cell counts in bronchoalveolar lavage (BAL) fluid

\begin{tabular}{|c|c|c|c|c|c|}
\hline & $\begin{array}{l}\text { Non-smokers } \\
(\mathrm{n}=10)\end{array}$ & $\begin{array}{l}\text { Healthy smokers } \\
(\mathrm{n}=12)\end{array}$ & $\begin{array}{l}\text { Stable COPD } \\
(n=7)\end{array}$ & $\begin{array}{l}\text { Severe exacerbations } \\
\text { of COPD } \\
(\mathrm{n}=7)\end{array}$ & $\begin{array}{l}\text { Very severe exacerbations } \\
\text { of COPD } \\
(\mathrm{n}=7 \text { ) }\end{array}$ \\
\hline Volume saline recovered (ml) & $60.0(7.4)$ & $47.2(5.5)$ & $15.3(3.8)^{* \star *} \dagger$ & $42.2(5.2)$ & $27.5(10.4)^{*}$ \\
\hline$\%$ recovery of saline & $40.6(4.2)$ & $31.1(3.8)$ & $15.6(2.4)^{* *}$ & $26.3(3.4)$ & $19.8(6.8)^{*}$ \\
\hline Total cell count $\left(\times 10^{3}\right)$ & $2.9(0.6)$ & $6.5(1.3)$ & $0.73(0.6)+\dagger$ & $3.74(0.5)$ & $43.7(38.4)^{*} \ddagger$ \\
\hline $\begin{array}{l}\text { \% Mononuclear (macrophage } \\
\text { and lymphocyte) }\end{array}$ & $95(2.6)$ & $94.5(2.2)$ & $80.6(6.2)$ & $63.7(12.4)$ & $49.1(14.3)^{*}+\dagger$ \\
\hline$\%$ Neutrophils & $4.8(2.6)$ & $4.9(1.6)$ & $17.9(5.6)$ & $41.4(12.5) \dagger$ & $50.7(14.3)^{*}+\dagger$ \\
\hline$\%$ Eosinophils & 0 & $0.3(0.2)$ & $0.6(0.6)$ & $0.1(0.1)$ & $0.3(0.2)$ \\
\hline \multicolumn{6}{|c|}{$\begin{array}{l}\text { Values are mean (SE). } \\
{ }^{*} p<0.05,{ }^{* *} p<0.01,{ }^{* * *} p<0.001 \text { compared with non-smokers. } \\
t p<0.05,+\uparrow p<0.01 \text { compared with smokers. } \\
\text { 士p }<0.05 \text { compared with severe COPD. } \\
\text { T } p<0.05 \text { compared with very severe COPD. }\end{array}$} \\
\hline
\end{tabular}

\section{BAL fluid cell counts}

The percentage recovery of BAL fluid and differential cell counts for BAL fluid leucocytes are shown in table 2. Significantly less fluid was aspirated in patients with moderate and very severe COPD than in non-smokers. The total BAL fluid cell count was significantly reduced in patients with moderate COPD and was significantly higher in those with very severe COPD than in healthy smokers and non-smokers, respectively. Patients with an exacerbation of COPD had increased numbers of neutrophils in the BAL fluid compared with healthy smokers and non-smokers. A concomitant decrease in mononuclear cells was seen in patients with very severe COPD. Moreover, the percentage of neutrophils present in the BAL fluid had a linear relationship with the $\mathrm{FEV}_{\mathrm{l}} / \mathrm{FVC}$ ratio $(r=-0.751, \mathrm{n}=34, \mathrm{p}<0.0001$; fig 1$)$.

\section{Measurements of oxidative stress}

Healthy smokers had considerably higher GSH levels than non-smokers or the COPD patient groups (fig 2). GSH levels in patients with COPD were significantly lower than in healthy smokers but were still higher than in healthy nonsmokers, with an even greater reduction observed during acute exacerbations.

\section{Inflammatory mediators}

TNF $\alpha$ and IL-8 levels were measured in large airway secretions and BAL fluid. TNF $\alpha$ levels detected in airway

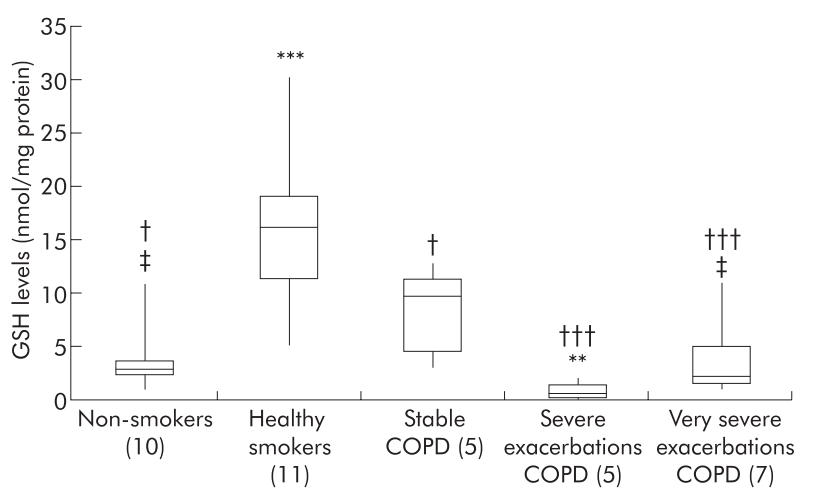

Figure 2 Assessment of oxidative stress locally in the lungs. Increased levels of glutathione (GSH) were seen in BAL fluid from asymptomatic smokers. Patients with moderate COPD were studied in a stable condition and patients with moderate or severe COPD were studied during an exacerbation. Data are expressed as medians with interquartile range (box) and range (whiskers); numbers of subjects shown in brackets. ANOVA $\mathrm{p}<0.0001 ;{ }^{* *} \mathrm{p}<0.01$ and ${ }^{* * *} \mathrm{p}<0.001 v$ non-smokers; $\uparrow \mathrm{p}<0.05$, $\uparrow \dagger \uparrow \mathrm{p}<0.001 v$ smokers; $\neq \mathrm{p}<0.01 v$ subjects with severe COPD exacerbations (multiple comparison post testing).
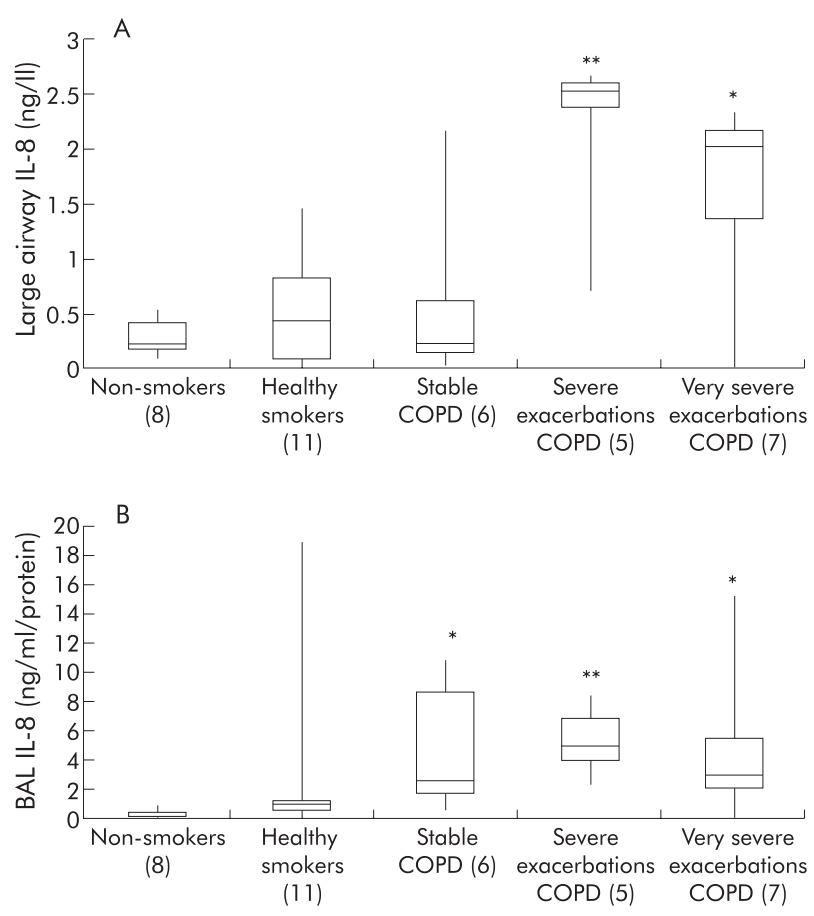

Figure 3 Assessment of inflammation in the airways. IL-8 levels were determined in (A) large airway secretions and (B) BAL fluid for the different subject groups. Data are expressed as medians with interquartile range (box) and range (whiskers); numbers of subjects are shown in brackets. ANOVA values were $p<0.01$ for large airway secretions and $p<0.001$ for BAL fluid; ${ }^{*} p<0.05$, ${ }^{* *} p<0.01 v$ nonsmokers (multiple comparison post testing).

secretions and BAL fluid were generally low and were not significantly different between the groups for either large airway secretions or BAL fluid (data not shown). Significantly higher levels of IL-8 were detected in large airway secretions during both severe and very severe exacerbations of COPD (fig 3A). Significantly higher levels of IL-8 were observed in the BAL fluid in all COPD patients, although the levels during exacerbations did not differ from those in stable patients (fig 3B). IL-8 levels in large airway samples had a linear relationship with the $\mathrm{FEV}_{\mathrm{l}} / \mathrm{FVC}$ ratio $(r=-0.592, \mathrm{p}<0.01, \mathrm{n}=29$; fig $4 \mathrm{~A})$; a similar relationship was seen in BAL fluid ( $r=-0.33, \mathrm{n}=35, \mathrm{p}=0.05$; fig $4 \mathrm{~B}$ ).

\section{Transcription factor nuclear translocation of NF- $\mathrm{B}$ in lung biopsies and BAL leucocytes}

Transcription factor DNA binding was assessed for nuclear proteins isolated from both bronchial biopsy specimens and 

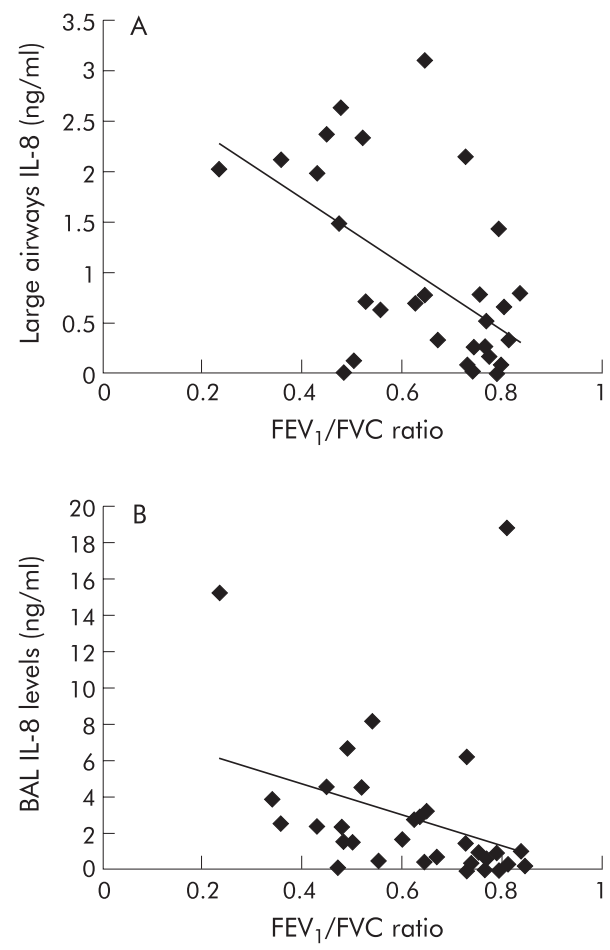

Figure 4 Relation between IL-8 levels and the $\mathrm{FEV}_{1} / \mathrm{FVC}$ ratio in $(\mathrm{A})$ the large airways and (B) BAL fluid. A significant linear relationship was evident in the large airways $(r=-0.592, n=29, p<0.001)$ and BAL fluid $(r=-0.33, n=35, p<0.0001)$ for all subjects.

BAL fluid leucocytes. From the samples obtained, this was only possible for non-smokers, healthy smokers, and those with severe exacerbations. NF- $\mathrm{BB}$ nuclear binding in BAL leucocytes was lower in healthy smokers than in nonsmokers (fig 5A), but this was not observed for leucocytes from patients with COPD. Patients with severe exacerbations of COPD had lower AP-1 nuclear binding in BAL fluid leucocytes than smokers or healthy subjects (fig $5 \mathrm{~B}$ ). There was insufficient sample to determine NF- $\mathrm{BB}$ or AP- 1 in BAL fluid leucocytes from patients with stable COPD. There was no significant difference in NF- $\mathrm{\kappa B}$ and AP-1 DNA binding activity in lung biopsy specimens (table 3), partly due to the small numbers available for analysis.

\section{DISCUSSION}

Increased neutrophils were found in the distal airspaces of patients with COPD, which increased further during exacerbations of the disease. The percentage of neutrophils in the distal airspace had a negative linear relationship with the severity of airways obstruction as assessed by the $\mathrm{FEV}_{1} / \mathrm{FVC}$ ratio. This increase in neutrophil numbers is concomitant with an increase in IL-8 levels in the proximal airway secretions in patients with stable and exacerbated COPD compared with smokers and non-smokers, and an increase in IL-8 levels in the distal airspaces in exacerbations of COPD. A new finding in this study is the depletion of GSH in the airspaces in exacerbations of COPD, indicating increased oxidative stress.

Although the pathological events that lead to the development of airways obstruction and exacerbations in COPD are still not completely understood, inflammation of the airways appears to be a critical factor. Indeed, by examining lung tissue sections, Hogg and colleagues found an increase in airways inflammation-evidenced by the enhanced presence of mucous exudates and inflammatory leucocytes-to be

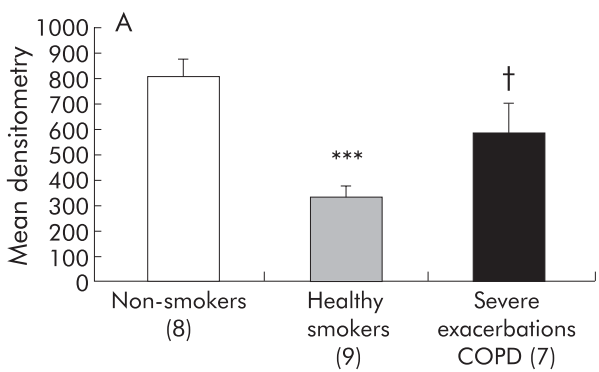

B

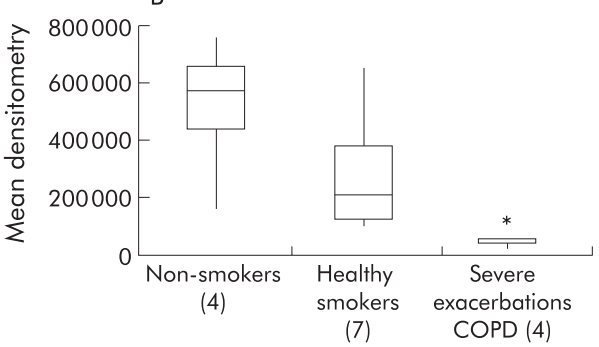

Figure 5 Electrophoretic mobility shift assays (EMSAs) for (A) NF- $\kappa B$ and (B) AP-1 DNA binding in BAL fluid leucocytes. Data are expressed as mean (SE) values or as medians with interquartile range (box) and range (whiskers) for the different subject groups; numbers of subjects are shown in brackets. Measurements for patients with stable COPD are not shown as DNA binding was only assessed in two samples for this group. ANOVA values were $p<0.001$ for NF- $\kappa B$ and $p<0.05$ for AP-1; $* * * \mathrm{p}<0.001 v$ controls; $\mathrm{tp}<0.05 v$ healthy smokers (multiple comparison testing).

associated with COPD disease severity. ${ }^{24}$ Oxidative stress is thought to be an important component of inflammation through the activation of oxidant sensitive transcription factors leading to increased transcription of pro-inflammatory genes. Critical to the effects of oxidative stress is the protective counterbalance of antioxidant systems. A shift in this oxidant/antioxidant balance could result in an increase in oxidative stress which may cause cellular damage. In this regard, GSH appears to be an important antioxidant in the lungs and is present in high concentrations in epithelial lining fluid..$^{14}$

A major limitation of our study is the fact that exacerbations were studied in patients with severe and very severe underlying COPD and compared with stable patients with moderate disease. Our interpretation of differences between exacerbations and the stable state may therefore actually be a reflection of differences in disease severity. However, increased numbers of neutrophils and their markers are seen in the airways during both severe and very severe exacerbations compared with stable disease and increased disease severity. ${ }^{25}{ }^{26}$ Also, exacerbations are more common with increasing disease severity. Thus, although we cannot directly attribute our findings to the exacerbated condition in our patients, exacerbations and disease severity are very much associated with regard to the inflammatory response. We have confirmed that patients with COPD have increased numbers of neutrophils in the distal airways compared with healthy smokers and non-smokers. We also found substantial increases in neutrophil numbers during severe exacerbations of the disease, particularly during very severe exacerbations resulting in respiratory failure and the need for mechanical ventilation. In contrast, we found a significantly lower total cell count in patients with stable moderate COPD than in healthy smokers and patients with very severe COPD. Linden and colleagues ${ }^{27}$ also reported a lower total cell count in patients with airways obstruction. The fact that IL-8 protein levels in BAL fluid in patients with stable COPD is 
Table 3 DNA binding of transcription factors NF- $\kappa B$ and AP-1 in lung biopsy specimens

\begin{tabular}{|c|c|c|c|c|}
\hline & Non-smokers & Healthy smokers & Stable COPD & $\begin{array}{l}\text { Very severe exacerbations } \\
\text { of COPD }\end{array}$ \\
\hline NF- $\mathrm{AP}$ & $\begin{array}{l}29.7(22.0-108.7) \\
(n=7) \\
12.6(0-40.0) \\
(n=4)\end{array}$ & $\begin{array}{l}116.3(64-199.7) \\
(n=4) \\
- \\
-\end{array}$ & $\begin{array}{l}74.9(45.9-127.4) \\
(n=3) \\
18.8(16.5-21.2) \\
(n=2)\end{array}$ & $\begin{array}{l}34.1(6.7-103.1) \\
(n=7) \\
40.5(32.6-48.3) \\
(n=2)\end{array}$ \\
\hline \multicolumn{5}{|c|}{$\begin{array}{l}\text { Data shown as median (IQR) values. } \\
\text { No biopsy specimens were obtained from patients with severe exacerbations of COPD. } \\
\text { No significant difference was detected between the groups for either NF- } \mathrm{kB} \text { or AP-1. }\end{array}$} \\
\hline
\end{tabular}

equivalent to levels detected during exacerbations suggests that the lower cell numbers in stable COPD is not due to difficulty in retrieving the lavage fluid. Furthermore, the highest cell counts recovered were for patients with very severe COPD where lavage fluid recovery is also low.

Although increased total cell counts and increased percentage neutrophils in sputum and BAL fluid have been reported previously, ${ }^{28-31}$ few studies have assessed inflammation in the airways during acute exacerbations of COPD. Qiu and colleagues $^{32}$ reported increased neutrophil recruitment and gene expression of neutrophil chemoattractant (CXC) receptors in bronchial biopsies from patients with acute severe exacerbations of COPD compared with those with stable COPD and non-smoking healthy subjects. Aaron and colleagues $^{26}$ measured sputum TNF $\alpha$ and IL-8 levels during exacerbations and found them to be significantly increased. Bhowmik et $a l^{2}$ examined sputum inflammatory markers in stable subjects who had frequent exacerbations and reported increased levels of IL- 8 and IL- 6 and total cell counts. In addition, more sputum and greater purulence of sputum was found over time during exacerbations, ${ }^{16}$ suggesting the presence of more inflammation over time. Previous reports in patients with mild exacerbations have shown an increase in eosinophil numbers ${ }^{33}$ that was not seen in our study of severe exacerbations of COPD. It should be noted that the patients in our study groups were not age matched, and those with moderate COPD and very severe COPD were significantly older than non-smokers and healthy smokers. This was unavoidable as the COPD patients attending the Royal Infirmary in Edinburgh constitute an older age group and the healthy individuals willing to participate in the study are not generally so elderly.

A role for IL-8 in the recruitment to and activation of neutrophils in the airways of patients with COPD has been proposed as it is detected in sputum and BAL fluid from patients with COPD. ${ }^{30}{ }^{34-36}$ Although Yamamoto et al ${ }^{36}$ found a negative correlation between IL-8 levels in sputum and $\mathrm{FEV}_{\mathrm{l}}$ / FVC in patients with stable COPD, we were unable to confirm that IL-8 levels are increased in large airway secretions from patients with moderate stable COPD but we did find increased IL-8 levels in the distal airspaces. Increased IL-8 levels and neutrophil numbers in BAL fluid have previously been reported in patients with stable COPD. ${ }^{31}$ No significant difference was found in TNF $\alpha$ levels in either large airways secretions or BAL fluid (data not shown). However, it should be noted that the DTT used to break up the sputum mucin can interfere with the measurement of TNF $\alpha$ by ELISA ${ }^{37}$ which might explain our lack of a result. Interestingly, IL-8 levels in both large airways secretions and BAL fluid had a negative linear relationship with the severity of airways obstruction as measured by the $\mathrm{FEV}_{\mathrm{l}} / \mathrm{FVC}$ ratio. It should be noted that these correlations were performed on all subjects-not just patients with COPD-because of the small numbers in individual groups. We found no evidence of a linear relationship between the percentage neutrophils and IL-8 levels in BAL fluid; however, such a relationship has been reported by other workers. ${ }^{638}$ These data therefore suggest that the IL-8 level may be useful as an indicator of disease severity and that, in addition to IL-8, other factors such as leukotriene $B 4^{31}$ may be responsible for the neutrophil influx in exacerbations and stable COPD.

It has been reported that the IL- 8 gene has both NF- $\kappa B$ and $\mathrm{AP}-1$ binding sites in the promoter region that regulates its transcriptional activation. ${ }^{39}$ Both NF- $\mathrm{\kappa B}$ and AP- 1 are oxidant sensitive transcription factors that have been implicated in the regulation of numerous pro-inflammatory mediators pertinent to lung inflammation. ${ }^{7}$ We therefore assessed the nuclear translocation of NF- $\kappa \mathrm{B}$ in bronchial biopsies and also in BAL fluid leucocyte populations. No significant difference in nuclear localisation of $\mathrm{NF}-\kappa \mathrm{B}$ was found in bronchial biopsies, although a trend was evident for increased NF- $\mathrm{KB}$ DNA binding in healthy smokers and patients with COPD. In contrast, BAL fluid leucocytes from healthy smokers showed a significant reduction in NF- $\mathrm{KB}$ DNA binding compared with non-smokers, while nuclear translocation of NF- $\mathrm{KB}$ during exacerbations of COPD did not differ from that in nonsmokers. Since we obtained enough BAL fluid leucocytes from only two patients with stable COPD to determine NF- $\kappa B$ nuclear translocation (data not shown), we were unable to make a comparison with samples obtained during exacerbations. However, we have previously reported a comparison of NF- $\kappa B$ DNA binding in sputum leucocytes from patients with stable and acute exacerbations of COPD and found a significant increase during exacerbations. ${ }^{8}$ There are reports in the literature of both increased and decreased NF- $\kappa B$ activity for cigarette smoke exposure in vitro. Cigarette smoke exposure in vitro reduced peripheral blood monocyte NF- $\kappa$ B DNA binding activity. ${ }^{40}{ }^{41}$ In contrast, acute cigarette smoke inhalation by guinea pigs induced NF- $\kappa B$ activation in alveolar macrophages. ${ }^{42}$ It appears that the variability in $\mathrm{NF}-\kappa \mathrm{B}$ activation/deactivation in response to cigarette smoke may be due to the site and cell type exposed and whether such exposure is acute or chronic.

A possible explanation for the reduced NF- $\kappa \mathrm{B}$ DNA binding in BAL fluid leucocytes may be the excessive production of oxidants such as hydrogen peroxide and nitric oxide during exacerbations which inactivate inhibitory $\kappa \mathrm{B}$ kinase (I kinase; IKK), ${ }^{44}$ the enzyme responsible for the phosphorylation of $I \kappa B \alpha$, resulting in its degradation and activation of

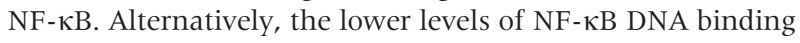
observed in BAL fluid leucocytes from healthy smokers may relate to the higher levels of antioxidants offering protection against oxidant stress by inhibiting NF- $\kappa \mathrm{B}$ activation and translocation to the nucleus, ${ }^{45}$ leading to less gene activation.

In accordance with the latter, and as previously reported, ${ }^{414}$ we found higher levels of the antioxidant GSH in BAL fluid in smokers. We now report, for the first time, the levels of GSH in the distal airspaces of patients with COPD. Patients with stable COPD had higher than normal GSH levels in the BAL fluid which became depleted during exacerbations of the disease. The lower levels of GSH found in smokers with COPD compared with healthy smokers could 
facilitate NF- $\kappa B$ activation leading to inflammation, which is evident in the increased neutrophil numbers and IL-8 levels in the BAL fluid.

In healthy smokers, and possibly in patients with stable COPD, the increased GSH levels in response to oxidative stress are associated with an enhanced expression of $\gamma$ glutamylcysteine synthetase ( $\gamma$-GCS), the main enzyme in the synthesis of GSH. ${ }^{15}$ In contrast, the reduced GSH levels in acute exacerbations may reflect an insufficient response to oxidative stress in the form of reduced $\gamma$-GCS activity resulting in lower GSH levels or direct depletion by an overwhelming oxidative burden from reactive oxygen species released by activated neutrophils. Support for the former mechanism comes from the observed decrease in DNA binding of the transcription factor AP- 1 which regulates $\gamma$ GCS in exacerbations of COPD. ${ }^{15} \gamma$-GCS, the rate limiting enzyme for GSH synthesis, was previously found to be downregulated in lung epithelial cells following acute exposure to cigarette smoke with a concomitant depletion of GSH. ${ }^{15}$ With inadequate protection, the lung tissue in these patients could be predisposed to injury. Indeed, in a study by Koul and colleagues, ${ }^{46}$ a decrease in lung GSH levels in mice exposed to cigarette smoke was associated with an increase in lipid peroxidation products. Assessment of lipid peroxidation markers in exhaled breath condensate also revealed an increase in patients with COPD compared with healthy smokers and non-smokers. ${ }^{47}$ Taken together, these data suggest an important role for GSH in the prevention of peroxidative lung damage in patients with COPD.

In conclusion, our data suggest that there is impaired antioxidant status in the peripheral airways of patients with stable COPD which is more pronounced in exacerbations. This is reflected in the presence of an inflammatory response, as shown by an increase in cell numbers and cytokine levels. A comparison of the parameters measured for very severe exacerbations compared with severe exacerbations of COPD revealed an increase only in the number of leucocytes in BAL fluid.

\section{ACKNOWLEDGEMENTS}

The authors thank all the subjects who participated in the study.

\section{Authors' affiliations}

E M Drost, W MacNee, ELEGI/Colt Laboratory, Centre for Inflammation Research, University of Edinburgh, Medical School, Edinburgh EH8 9AG, UK

K M Skwarski, W MacNee, Royal Infirmary Edinburgh, Little France, Edinburgh EH16 4SA, UK

J Sauleda, A Agusti, Servei de Pneumologia and Unitat d'investigacio, Hospital Universitari son Dureta, Palma de Mallorca, Spain

N Soler, J Roca, Servei de Pneumologia (ICPCT), Hospital Clinic, IDIBAPS, Universitat de Barcelona, Barcelona, Spain

The study was funded by Novartis Pharmaceutical Company, Horsham, UK, and part funded by FIS 00/0281 and Red Respira (RTIC C03/011 Fondo de Investigacion Sanitaria).

\section{REFERENCES}

1 Keatings VM, Barnes PJ. Granulocyte activation markers in induced sputum: comparison between chronic obstructive pulmonary disease, asthma, and normal subjects. Am J Respir Crit Care Med 1997;155:449-53.

2 Bhowmik A, Seemungal TA, Sapsford RJ, et al. Relation of sputum inflammatory markers to symptoms and lung function changes in COPD exacerbations. Thorax 2000;55:1 14-20.

3 Paredi P, Kharitonov SA, Leak D, et al. Exhaled ethane, a marker of lipid peroxidation, is elevated in chronic obstructive pulmonary disease. Am J Respir Crit Care Med 2000;162:369-73.

4 Morrison D, Rahman I, Lannan S, et al. Epithelial permeability, inflammation, and oxidant stress in air spaces of smokers. Am J Respir Crit Care Med 1999;159:473-9.

5 Rahman I, Morrison D, Donaldson K, et al. Systemic oxidative stress in asthma, COPD, and smokers. Am J Respir Crit Care Med 1996; 154:1055-60.
6 Pesci A, Balbi B, Majori M, et al. Inflammatory cells and mediators in bronchial lavage of patients with chronic pulmonary disease. Eur Respir $J$ 1998;12:380-6.

7 Rahman I, MacNee W. Regulation of redox glutathione levels and gene transcription in lung inflammation: therapeutic approaches. Free Radic Biol Med 2000;28:1405-20.

8 Drost EM, Ritchie HE, Skwarska E, et al. NF- $\mathrm{KB}$ activation in airway leucocytes in COPD patients. Eur Respir J 2001;16:260s.

9 MacNee W, Wiggs B, Belzberg AS, et al. The effect of cigarette smoking on neutrophil kinetics in human lungs. N Engl J Med 1989:321:924-8.

10 Selby C, Drost E, Lannan S, et al. Neutrophil retention in the lungs of patients with chronic obstructive pulmonary disease. Am Rev Respir Dis 1991; 143:1359-64.

11 Drost EM, Selby C, Bridgeman MM, et al. Decreased leukocyte deformability after acute cigarette smoking in humans. Am Rev Respir Dis 1993; 148:1277-83

12 Li XY, Rahman I, Donaldson K, et al. An investigation of the mechanism of the increased epithelial permeability induced by cigarette smoking in vivo and in vitro models. Am J Respir Crit Care Med 1994;149:1518-25.

13 Rahman I, Li XY, Donaldson K, et al. Glutathione homeostasis in alveolar epithelial cells in vitro and lung in vivo under oxidative stress. Am J Physiol 1995;269:L285-92.

14 Cantin AM, North SL, Hubbard RC, et al. Normal alveolar epithelial lining fluid contains high levels of glutathione. J Appl Physiol 1987;63:152-7.

15 Rahman I, Smith CA, Lawson MF, et al. Induction of gamma-glutamylcysteine synthetase by cigarette smoke is associated with AP-1 in human alveolar epithelial cells. FEBS Lett 1996;396:21-5.

16 Donaldson GC, Seemungal TA, Patel IS, et al. Longitudinal changes in the nature, severity and frequency of COPD exacerbations. Eur Respir J 2003;22:931-6.

17 Pauwels RA, Buist AS, Calverley PMA, et al. Global strategy for the diagnosis, management, and prevention of chronic obstructive pulmonary disease. NHLBI/WHO Global Initiative for Chronic Obstructive Lung Disease (GOLD) Workshop Summary. Am J Respir Crit Care Med 2001;163:1256-76.

18 Celli BR, MacNee W. Standards for the diagnosis and treatment of patients with COPD: a summary of the ATS/ERS position paper. Eur Respir $J$ 2004:23:932-46.

19 Kelly CA, Kotre CJ, Ward C, et al. Anatomical distribution of bronchoalveolar lavage fluid as assessed by digital subtraction radiography. Thorax 1987;42:624-8.

20 Tietze $\mathrm{F}$. Enzymic method for quantitative determination of nanogram amounts of total and oxidised glutathione: applications to mammalian blood and other tissues. Anal Biochem 1969;27:502-22

21 Vandeputte C, Guizon I, Genestie-Denis I, et al. A microtiter plate assay for total glutathione and glutathione disulfide contents in cultured/isolated cells: performance study of a new miniaturized protocol. Cell Biol Toxicol 1994:10:415-21.

22 Andrews NC, Faller DV. A rapid micropreparation technique for extraction of DNA-binding proteins from limiting numbers of mammalian cells. Nucl Acids Res 1991;19:2499.

23 Gilmour PS, Brown DM, Beswick PH, et al. Free radical activity of industria fibres: role of iron in oxidative stress and activation of transcription factors. Environ Health Perspect 1997; 105(Suppl 5):1313-7.

24 Hogg JC, Chu F, Utokaparch S, et al. The nature of small-airway obstruction in chronic obstructive pulmonary disease. N Engl J Med 2004;350:2645-53.

25 Di Stefano A, Capelli A, Lusuardi M, et al. Severity of airflow limitation is associated with severity of airway inflammation in smokers. Am J Respir Crit Care Med 1998; 158:1277-85

26 Aaron SD, Angel JB, Lunau M, et al. Granulocyte inflammatory markers and airway infection during acute exacerbations of chronic obstructive pulmonary disease. Am J Respir Crit Care Med 2001;163:349-55.

27 Linden M, Rasmussen JB, Piitulainen E, et al. Airway inflammation in smokers with nonobstructive and obstructive chronic bronchitis. Am Rev Respir Dis 1993; 148:1226-32

28 Peleman RA, Rytila PH, Kips JC, et al. The cellular composition of induced sputum in chronic obstructive pulmonary disease. Eur Respir J 1999; 13:839-43

29 Yildiz F, Kaur AC, Ilgazli A, et al. Inhaled corticosteroids may reduce neutrophilic inflammation in patients with stable chronic obstructive pulmonary disease. Respiration 2000;67:71-6.

30 Keatings VM, Collins PD, Scott DM, et al. Differences in interleukin-8 and tumour necrosis factor- $\alpha$ in induced sputum from patients with chronic obstructive pulmonary disease and asthma. Am J Respir Crit Care Med 1996; 153:530-4

31 Tanino M, Betsuyaku T, Takeyabu K, et al. Increased levels of interleukin-8 in BAL fluid from smokers susceptible to pulmonary emphysema. Thorax 2002;57:405-11

32 Qiu Y, Zhu J, Bandi V, et al. Biopsy neutrophilia, neutrophil chemokine and receptor gene expression in severe exacerbations of chronic obstructive pulmonary disease. Am J Respir Crit Care Med 2003;168:968-75.

33 Saetta M, Stefano AD, Turato G, et al. Airway eosinophilia in chronic bronchitis during exacerbations. Am J Respir Crit Care Med 1994; 150:1646-52.

34 Nocker RET, Schoonbrood DFM, van de Graaf EA, et al. Interleukin-8 in airway inflammation in patients with asthma and chronic obstructive pulmonary disease. Int Arch Allergy Immunol 1996; 109:183-91.

35 Richman-Eisenstat JBY, Jorens PG, Herbert CA, et al. Interleukin-8: an important chemoattractant in sputum of patients with chronic inflammatory airway diseases. Am J Physiol: Lung Cell Mol Physiol 1993;264:L413-8.

36 Yamamoto C, Yoneda T, Yoshikawa M, et al. Airway inflammation in COPD assessed by sputum levels of interleukin-8. Chest 1997;112:505-10. 
37 Woolhouse IS, Bayley DL, Stockley RA. Effect of sputum processing with dithiothreitol on the detection of inflammatory mediators in chronic bronchitis and bronchiectasis. Thorax 2002;57:667-71.

38 Soler N, Ewig S, Torres A, et al. Airway inflammation and bronchial microbial patterns in patients with stable chronic obstructive pulmonary disease. Eur Respir J 1999:14:1015-22.

39 Roebuck KA Regulation of interleukin-8 gene expression. J Interferon Cytokine Res 1999; 19:429-38

40 Vayssier $M$, Favatier $F$, Pinot $F$, et al. Tobacco smoke induces coordinate activation of HSF and inhibition of NFkappaB in human monocytes: effects on TNF $\alpha$ release. Biochem Biophys Res Commun 1998;252:249-56.

41 Favatier F, Polla BS. Tobacco smoke-inducible human haem oxygenase- 1 gene expression: role of distinct transcription factors and reactive oxygen intermediates. Biochem J 2001;35:475-82.

42 Nishikawa, M, Kakemizu N, Ito T, et al. Superoxide mediates cigarette smoke-induced infiltration of neutrophils into the airways through nuclear
factor-kappaB activation and IL-8 mRNA expression in guinea pigs in vivo. Am J Respir Cell Mol Biol 1999;20:189-98.

43 Reynaert NL, Ckless K, Korn SH, et al. Nitric oxide represses inhibitory kappaB kinase through S-nitrosylation. Proc Natl Acad Sci USA 2004;101:8945-50.

44 Korn SH, Wouters EF, Vos N, et al. Cytokine-induced activation of nuclear factor-kappa $B$ is inhibited by hydrogen peroxide through oxidative inactivation of IKB kinase. J Biol Chem 2001;276:35693-700.

45 Hirota K, Murata M, Sachi Y, et al. Distinct roles of thioredoxin in the cytoplasm and in the nucleus. A two-step mechanism of redox regulation of transcription factor NF-kappaB. J Biol Chem 1999;274:27891-7.

46 Koul A, Bhatia V, Bansal MP. Effect of alpha-tocopherol on pulmonary antioxidant defence system and lipid peroxidation in cigarette smoke inhaling mice. BMC Biochemistry 2001;2:14.

47 Montuschi P, Collins JV, Ciabattoni G, et al. Exhaled 8-isoprostane as an in vivo biomarker of lung oxidative stress in patients with COPD and healthy smokers. Am J Respir Crit Care Med 2000;162:1175-7.

\section{LUNG ALERT}

Induced sputum for the diagnosis of paediatric pulmonary TB

$\Delta$ Zar HJ, Hanslo D, Apolles $P$, et al. Induced sputum versus gastric lavage for microbiological confirmation of pulmonary tuberculosis in infants and young children: a prospective study. Lancet 2005;365:130-4.

a putum induction in adults is a well recognised method of diagnosing pulmonary tuberculosis (TB). However, in children this technique is not regarded as feasible since young children tend to swallow their sputum and do not expectorate. Gastric lavage has been used to obtain microbiological confirmation in children but this requires an overnight fast, repeated specimens, and admission to hospital.

This 2 year study carried out in Cape Town, South Africa compared the yield of Mycobacterium tuberculosis from repeated induced sputum samples with that from gastric lavage in young children from an area with a high rate of HIV and TB. 250 children with suspected TB were studied, the median age being 13 months. A positive smear or culture was obtained from 62 children (25\%). Samples from induced sputum and gastric lavage were positive in $54(87 \%)$ and $40(65 \%)$, respectively. Microbiological yield did not differ between HIV infected and HIV uninfected children. Sputum induction was well tolerated, with minor side effects of increased cough, epistaxis, vomiting, and wheeze.

This study shows that sputum induction is safe and useful for microbiological confirmation of pulmonary TB in infants and young children. The authors conclude that this technique is preferable to gastric lavage.

M Wijesinghe SpR in Respiratory Medicine, Royal United Hospital, Bath, UK; memew@doctor.com 